\title{
Characterization of a novel halophilic archaeon, Halobiforma haloterrestris gen. nov., sp. nov., and transfer of Natronobacterium nitratireducens to Halobiforma nitratireducens comb. nov.
}

\footnotetext{
${ }^{1}$ Institut für Mikrobiologie der Westfälischen Wilhelms-Universität Münster, Corrensstr. 3, D-48149 Münster, Germany

2 DSMZ-Deutsche Sammlung für Mikroorganismen und Zellkulturen $\mathrm{GmbH}$, Mascheroder Weg 1b, D-38124 Braunschweig, Germany
}

\author{
F. F. Hezayen, ${ }^{1}$ B. J. Tindall, ${ }^{2}$ A. Steinbüchel ${ }^{1}$ and B. H. A. Rehm ${ }^{1}$ \\ Author for correspondence: Bernd Rehm. Tel: +49 2518339848 . Fax: +49 2518338388. \\ e-mail: rehm@uni-muenster.de
}

\begin{abstract}
Strain $135^{\top}$, a novel red-pigmented, aerobic, extremely halophilic member of the Archaea showing rod, coccus and slightly pleomorphic morphology, was isolated from hypersaline soil close to Aswan (Egypt). This organism is neutrophilic, motile and requires at least $2 \cdot 2 \mathrm{M} \mathrm{NaCl}$, but no $\mathrm{MgCl}_{2}$, for growth and exhibits optimal growth at $42{ }^{\circ} \mathrm{C}$. Polar lipid analysis revealed the presence of sulfated triglycosyl diether and triglycosyl diether as the sole glycolipids as well as the absence of the glycerol diether analogue of phosphatidyl glycerosulfate. C20: C20 and C20: C25 core lipids are present in almost equal proportions. The G+C content of the DNA is $66.9 \mathrm{~mol} \%$. 16S rDNA analysis revealed that strain $135^{\top}$ was a member of the phyletic group defined by the family Halobacteriaceae, but there was a low degree of similarity to other members of this family. Highest similarity values of $96 \cdot 4$ and $93 \cdot 8-94 \cdot 3 \%$ were obtained to the 16S rDNA of Natronobacterium nitratireducens and Natronobacterium gregoryi, Natronococcus occultus and Natronococcus amylolyticus. Strain $135^{\top}$ is able to accumulate polyhydroxybutyrate as intracellular reserve material. On the basis of the data presented, strain 135 should be placed in a new genus, Halobiforma gen. nov. as Halobiforma haloterrestris sp. nov. The type strain is strain $135^{\top}$ ( = DSM $13078^{\top}=\mathrm{JCM}$ $\left.11627^{\top}\right)$. Moreover, the transfer of Natronobacterium nitratireducens to Halobiforma nitratireducens comb. nov. is proposed.
\end{abstract}

Keywords: Halobiforma haloterrestris, nitratireducens, halophilic, archaea, polyhydroxybutyrate

\section{INTRODUCTION}

The aerobic, extremely halophilic archaea that belong to the family Halobacteriaceae, order Halobacteriales, class Haloarchaea, are chemo-organotrophic organisms that use amino acids or carbohydrates to grow and need at least $1.5 \mathrm{M} \mathrm{NaCl}$ for growth; most exhibit optimal growth at 3.5-4.5 M NaCl (Grant et al., 2001). Except for some members of the genus Natrialba, which are non-pigmented, all members of the family

Abbreviations: PHB, poly- $\beta$-hydroxybutyrate; VPMR, Voges-Proskauer methyl red.

The GenBank/EMBL/DDBJ accession number for the $16 \mathrm{~S}$ rDNA sequence of strain $135^{\top}$ is AF333760.
Halobacteriaceae are red-pigmented due to the presence of carotenoids (Kamekura \& Dyall-Smith, 1995; Hezayen et al., 2001; Grant et al., 2001). Before the 1970s, halobacterial taxonomy was based mainly on standard biochemical tests and morphology (Gibbons, 1974). The current taxonomy is based largely on $16 \mathrm{~S}$ rDNA sequences and chemotaxonomic criteria, particularly polar lipid composition, which has induced a further reclassification of some uncertain halophilic species and the creation of new genera (Grant \& Larsen, 1989; Ross \& Grant, 1985; Kamekura \& Dyall-Smith, 1995; Kamekura et al., 1997). The availability of complete $16 \mathrm{~S}$ rDNA sequences of many haloarchaea has resulted in the recognition of even more diversity at the genus level within the family 
Halobacteriaceae (Kamekura \& Dyall-Smith, 1995; McGenity \& Grant, 1995). This has resulted in a dramatic increase in the number of these halophilic taxa. Fifteen genera of the family Halobacteriaceae have been described: Halobacterium, Haloarcula, Haloferax, Halococcus, Halorubrum, Halogeometricum, Haloterrigena, Halobaculum, Halorhabdus, Natrialba, Natrinema, Natronobacterium, Natronococcus, Natronorubrum and Natronomonas (Tindall et al., 1984; Torreblanca et al., 1986; Kamekura \& Dyall-Smith, 1995; McGenity \& Grant, 1995; Oren et al., 1995; Kamekura et al., 1997; McGenity et al., 1998; Montalvo-Rodríguez et al., 1998; Xu et al., 1999; Ventosa et al., 1999; Wainø et al., 2000; Grant et al., 2001). However, differences in the evolutionary rates in various groups of organisms prevent the use of phylogenetic parameters alone in delineating taxa; consequently, the use of $16 \mathrm{~S}$ rDNA sequences alone to describe taxa is not enough and the combination of genotypic and phenotypic characteristics (polyphasic taxonomy) constitutes a practical solution to the delineation of taxa (Oren et al., 1997).

In this paper, $1457 \mathrm{bp}$ of the $16 \mathrm{~S}$ rDNA sequence from the halophilic organism strain $135^{\mathrm{T}}$ is reported as well as polar lipid analysis and physiological and biochemical characteristics. Based on the data presented, we found that strain $135^{\mathrm{T}}$ is not identical to any of the present species and is sufficiently different from them to justify classification as a novel species within a new genus. In addition, our findings also support the removal of Natronobacterium nitratireducens (Xin et al., 2001) from the genus Natronobacterium and its placement in the same genus as the novel isolate, as Halobiforma nitratireducens comb. nov.

\section{METHODS}

Archaeal strain. Strain $135^{\mathrm{T}}\left(=\mathrm{DSM} 13078^{\mathrm{T}}=\mathrm{JCM} 11627^{\mathrm{T}}\right)$ was isolated from a soil sample that was collected from the surface of a hypersaline soil (Aswan, Egypt), using S-G medium [containing $\left(\mathrm{l}^{-1}\right): 250 \mathrm{~g} \mathrm{NaCl}, 2 \mathrm{~g} \mathrm{KCl}, 20 \mathrm{~g}$ $\mathrm{MgSO}_{4} \cdot 7 \mathrm{H}_{2} \mathrm{O}, 10 \mathrm{~g}$ Casamino acids, $7 \cdot 5 \mathrm{~g}$ yeast extract, $3 \mathrm{~g}$ sodium citrate; Sehgal \& Gibbons, 1960]. Soil particles were spread on the surface of $S-G$ agar plates and were then incubated in sealed plastic bags at $40{ }^{\circ} \mathrm{C}$. After 2 weeks incubation, several pigmented colonies appeared on the agar plates. A representative red colony for strain $135^{\mathrm{T}}$ was transferred to S-G broth medium and was grown at $40^{\circ} \mathrm{C}$. To ensure the selection of a pure colony, serial dilutions were made from liquid growth and spread on agar plates. After 2 weeks incubation at $40^{\circ} \mathrm{C}$, a single colony was picked and was used for further study.

Media and growth conditions. The isolation medium $\mathrm{S}-\mathrm{G}$ was also used for physiological characterization as well as cell maintenance. Salt-minerals medium was used to test the utilization of different organic substrates, either nitrogenous or non-nitrogenous, as nitrogen and/or carbon and energy sources and it contained $\left(\mathrm{l}^{-1}\right): 250 \mathrm{~g} \mathrm{NaCl}, 2 \mathrm{~g} \mathrm{KCl}, 5 \mathrm{~g}$ $\mathrm{MgSO}_{4} \cdot 7 \mathrm{H}_{2} \mathrm{O}, 2 \mathrm{~g} \mathrm{NH}_{4} \mathrm{Cl}$, supplemented with $1 \%(\mathrm{w} / \mathrm{v})$ of the tested substrate. The basal medium is the salt-minerals medium supplemented with $0 \cdot 1 \%(\mathrm{w} / \mathrm{v})$ yeast extract and was used for biochemical characterization as mentioned previously (Hezayen et al., 2001). Unless indicated otherwise, the $\mathrm{pH}$ was adjusted to $7 \cdot 5$ with $1 \mathrm{M} \mathrm{NaOH}$ and media were sterilized by autoclaving. Agar plates were prepared by adding $2 \%(\mathrm{w} / \mathrm{v})$ agar before autoclaving.

Light microscopic examination. Gram staining was performed by using acetic-acid-fixed samples as described by Dussault (1955). Wet mounts were prepared to detect motility, cell shape and cell dimensions from various growth stages from both broth and solid $\mathrm{S}-\mathrm{G}$ medium at different $\mathrm{NaCl}$ concentrations and were examined with an Ortholux II microscope (Leitz).

Physiological and biochemical characterization. The growth response to $\mathrm{NaCl}$ was examined in liquid and solid $\mathrm{S}-\mathrm{G}$ medium by using serial $\mathrm{NaCl}$ concentrations ranging from 50 to $320 \mathrm{~g}^{-1}$ and to $\mathrm{pH}$ by testing growth at $\mathrm{pH} \mathrm{5-10.} \mathrm{The}$ growth response to temperature was examined by testing growth in liquid and in $\mathrm{S}-\mathrm{G}$ agar at up to $60^{\circ} \mathrm{C}$. The requirement for $\mathrm{Mg}^{2+}$ for growth was tested qualitatively by growing the strain in $\mathrm{S}-\mathrm{G}$ liquid medium with and without $\mathrm{MgSO}_{4} \cdot 7 \mathrm{H}_{2} \mathrm{O}$. Growth was monitored in liquid cultivations by Klett photometer. Catalase and oxidase activities were tested according to Gerhardt et al. (1994). Hydrolysis of starch, gelatin, casein and lipids, esterase and urease activities, nitrate reduction, indole formation from tryptone, hydrogen sulfide production, citrate utilization and VogesProskauer and methyl red (VPMR) reactions were performed according to Gerhardt et al. (1994) as mentioned previously (Hezayen et al., 2001). Production of acid from sugars was tested as described previously (Hezayen et al., 2001). Utilization of $n$-butyric acid, xylose, arabinose, fructose, glucose, galactose, sucrose, maltose, lactose, starch, mannitol, sorbitol, citrate, gluconate, acetate, pyruvate, glycerine, bacto-peptone, gelatin, nutrient broth, glycine, proteose peptone, Casamino acids and tryptone as sole nitrogen and/or carbon and energy sources was performed in the salt-minerals medium supplemented with $1 \%(\mathrm{w} / \mathrm{v})$ substrate. In the case of non-nitrogenous compounds, $0 \cdot 2 \%(\mathrm{w} / \mathrm{v}) \mathrm{NH}_{4} \mathrm{Cl}$ was supplied as the sole nitrogen source and the test was also performed in the basal medium. In the case of sugars, the test medium was buffered with $20 \mathrm{mM}$ PIPES. Growth was monitored with a Klett photometer.

Antibiotic susceptibility. The susceptibility of the strain to antibiotics was determined as described previously (Hezayen et al., 2001). The following antibiotics were tested ( $\mu \mathrm{g}$ per disc unless indicated otherwise): penicillin $\mathrm{G}$ (5), chloramphenicol (10), tetracycline (30), streptomycin (25), nitrofurantoin (300), bacitracin (10 U), novobiocin (5), fusidic acid (10), anisomycin (20), trimethoprim (2.5), rifampicin (30), nystatin (100 U), nalidixic acid (30) and erythromycin (15).

Carotenoid extraction. Carotenoids were extracted with methanol/acetone $(1: 1, \mathrm{v} / \mathrm{v})$ as described by Gochnauer et al. (1972) from cells that were grown on agar plates and in S-G broth. Carotenoids were also tested in the water lysate from cells grown in $\mathrm{S}-\mathrm{G}$ broth and the absorption spectrum was determined by wavelength scan using an Ultrospec 2000 photometer (Pharmacia Biotech) in the wavelength range 300-700 nm.

Polymer isolation and analysis. Intracellular accumulation of the polymer poly- $\beta$-hydroxybutyrate (PHB) was tested from cells grown for 8 days in $\mathrm{S}-\mathrm{G}$ broth and in the basal medium supplemented with $1 \%(\mathrm{v} / \mathrm{v})$ butyric acid or $1 \%(\mathrm{w} / \mathrm{v})$ proteose peptone; the polymer was analysed and isolated as described previously in detail (Hezayen et al., 2000). 
Detection of diether lipids. Diether lipids were released from $100 \mathrm{mg}$ freeze-dried cells using comparatively mild hydrolytic methods that did not lead to significant cleavage of hydroxylated isoprenoid ether lipids, as described previously (Hezayen et al., 2001).

Extraction of respiratory lipoquinones and polar lipids. Respiratory lipoquinones and polar lipids were extracted from $100 \mathrm{mg}$ freeze-dried cell material using the two-stage method of Tindall (1990a, b).

Analysis of polar lipids. Polar lipids were separated by twodimensional silica gel TLC. Total lipid material and specific functional groups were detected using dodecamolybdophosphoric acid (total lipids) (see Hezayen et al., 2001).

Isolation of genomic DNA and 16S rDNA amplification and sequencing. DNA was extracted from cells lysed in distilled water by phenol/chloroform extraction followed by ethanol precipitation, modified according to Mak \& Ho (1992). The gene encoding 16S rRNA was amplified by PCR with the forward primer 5'-GCCGGAGGTCATTGCTAGTGGAGTC-3' (corresponding to Halobacterium cutirubrum NCIMB 763 positions 16-40) and the reverse primer 5'AGGAGGTGATCCAGCCGCAGATTCC-3' (corresponding to Hbt. cutirubrum NCIMB 763 positions 1472-1448). PCR was performed for 30 cycles with denaturation for $30 \mathrm{~s}$ at $95^{\circ} \mathrm{C}$, annealing for $1 \mathrm{~min}$ at $40^{\circ} \mathrm{C}$ and polymerization for $3 \mathrm{~min}$ at $72^{\circ} \mathrm{C}$. The amplified $16 \mathrm{~S}$ rDNA was cloned into vector pGEM-T Easy (Promega) and recombinant plasmids were propagated in Escherichia coli XL-1 Blue (Stratagene). The sequence of the 16S rDNA was determined by the chain-termination method using an automatic LI-COR model 4000L sequencer (MWG-Biotech). Standard universal and reversal sequencing primers as well as synthetic oligonucleotides were used as primers, and the 'primer-hopping' strategy was employed. Phylogenetic analysis was performed as outlined previously (Rehm, 2001). Initial investigations on the global $16 \mathrm{~S}$ rDNA sequencebased position of the novel isolate used the ARB database (Ludwig \& Strunk, 1996). On the basis of this work, the 16S rDNA sequences were compared with the existing $16 \mathrm{~S}$ rDNA database for members of the phyletic group defined as members of the family Halobacteriaceae. A greater degree of resolution among closely related taxa was achieved using sequences aligned using CLUSTAL X. Similarity values were calculated based on the aligned 16S rDNA sequences from the following micro-organisms: Nbt. nitratireducens $\mathrm{C} 231^{\mathrm{T}}$ (AB045012), Natronobacterium gregoryi NCIMB $2189^{\mathrm{T}}$ (D87970), Natronococcus occultus NCIMB 2192 ${ }^{\mathrm{T}}$ (Z88378), Natrialba magadii NCIMB 2190 ${ }^{\mathrm{T}}$ (X72495), Natrialba asiatica 172 $\mathrm{P}^{\mathrm{T}}$ (D14123), Halococcus sp. JCM 8979 (D63786), strain $135^{\mathrm{T}}$ (= DSM $13078^{\mathrm{T}}$ ) and Natronococcus amylolyticus Ah-36 ${ }^{\mathrm{T}}$ (D43628). Similarity values quoted between any two organisms are their binary similarity values. 16S rDNA-based dendrograms were generated using the following programs from PHYLIP: DNAPARS, DNAML, FITCH, KITCH and NEIGHBOR.

G + C content of the DNA. This was determined according to Mesbah et al. (1989) and Tamaoka \& Komagata (1984) as described previously (Hezayen et al., 2001).

\section{RESULTS AND DISCUSSION}

Strain $135^{\mathrm{T}}$ was isolated from hypersaline soil close to Aswan, Egypt. On the basis of its pigmentation, NaCldependent growth, antibiotic susceptibility, chemical composition and $16 \mathrm{~S}$ rDNA sequence, strain $135^{\mathrm{T}}$ was identified as a member of the family Halobacteriaceae. The 16S rDNA similarity values and $\mathrm{G}+\mathrm{C}$ content of strain $135^{\mathrm{T}}$ indicate that it represents a novel species (see Fig. 4). However, it is also possible to distinguish this organism from all other genera described within the family Halobacteriaceae by evaluating the phenotypic data (see Figs 1-3).

\section{Morphology, physiology and biochemistry}

Colonies of strain $135^{\mathrm{T}}$ formed on $\mathrm{S}-\mathrm{G}$ agar plates were circular, flat or slightly elevated, entire, small and measured around $1 \mathrm{~mm}$ in diameter, opaque, glossy and red-pigmented.

Strain $135^{\mathrm{T}}$ was capable of growing over a wide range of $\mathrm{NaCl}$ concentrations ranging from $13-14 \%(\mathrm{w} / \mathrm{v})$ to saturation in liquid $\mathrm{S}-\mathrm{G}$ medium. The strain grew optimally in the presence of $20 \%(\mathrm{w} / \mathrm{v}) \mathrm{NaCl}$, as has been shown for most extremely halophilic archaea, which grow optimally in the range $20-26 \%(\mathrm{w} / \mathrm{v})$ $\mathrm{NaCl}$ (Grant et al., 2001). $\mathrm{NaCl}$ could be partially replaced by $\mathrm{KCl}$, showing growth at $6 \%(\mathrm{w} / \mathrm{v}) \mathrm{NaCl}$ in the presence of $12 \%(\mathrm{w} / \mathrm{v}) \mathrm{KCl}$, but no growth was observed at $3 \%(\mathrm{w} / \mathrm{v}) \mathrm{NaCl}$ in the presence of $12 \%$ (w/v) $\mathrm{KCl}$. Addition of $\mathrm{Mg}^{2+}$ was not required for growth.

Cells of strain $135^{\mathrm{T}}$ showed completely different cell shapes when grown in liquid and solid media (Figs 1 and 2). Cells from liquid cultivations lysed in water as well as in $1 \%(\mathrm{w} / \mathrm{v})$ bacto-peptone, even in the presence of $25 \%(\mathrm{w} / \mathrm{v}) \mathrm{NaCl}$, like rod-shaped halophilic archaea, while cells from agar plates (cocci) did not lyse, like the coccus-shaped halophilic archaea (Kamekura et al., 1988). Among the members of the family Halobacteriaceae, only the alkaliphilic species Nbt. gregoryi has been briefly described to appear as rods in liquid cultivations and as spherical cells on solid medium (Tindall et al., 1984). Cells stained Gramnegative. When a liquid medium was inoculated with cells grown on solid medium, the rod shapes appeared and, when solid medium was inoculated with cells from liquid medium, the coccus-shaped cells appeared.

The optimum growth temperature in $\mathrm{S}-\mathrm{G}$ medium containing $20 \%$ (w/v) $\mathrm{NaCl}$ was $42{ }^{\circ} \mathrm{C}$ and the maximum temperature at which growth was observed was $58^{\circ} \mathrm{C}$. Although the isolate is, based on 16S rDNA similarity, related to the alkaliphilic species $\mathrm{Nbt}$. gregoryi, Nbt. nitratireducens, Ncc. occultus and Ncc. amylolyticus, it exhibited neutrophilic growth characteristics over a $\mathrm{pH}$ range of $6-9 \cdot 2$ at $42{ }^{\circ} \mathrm{C}$ in the presence of $20 \%(\mathrm{w} / \mathrm{v}) \mathrm{NaCl}$, showing best growth at $\mathrm{pH} 7 \cdot 5$; this clearly separates the novel isolate from the former species. The isolate was tested for its ability to use different substrates for growth (see above): none of the tested non-nitrogenous compounds could serve as the sole carbon source in the presence of $\mathrm{NH}_{4} \mathrm{Cl}$ as the sole nitrogen source but, when the test medium was supplemented with $0 \cdot 1 \%(\mathrm{w} / \mathrm{v})$ yeast extract, only glycerol, sucrose, arabinose, glucose, maltose, acetate, pyruvate and $n$-butyric acid were used for weak 

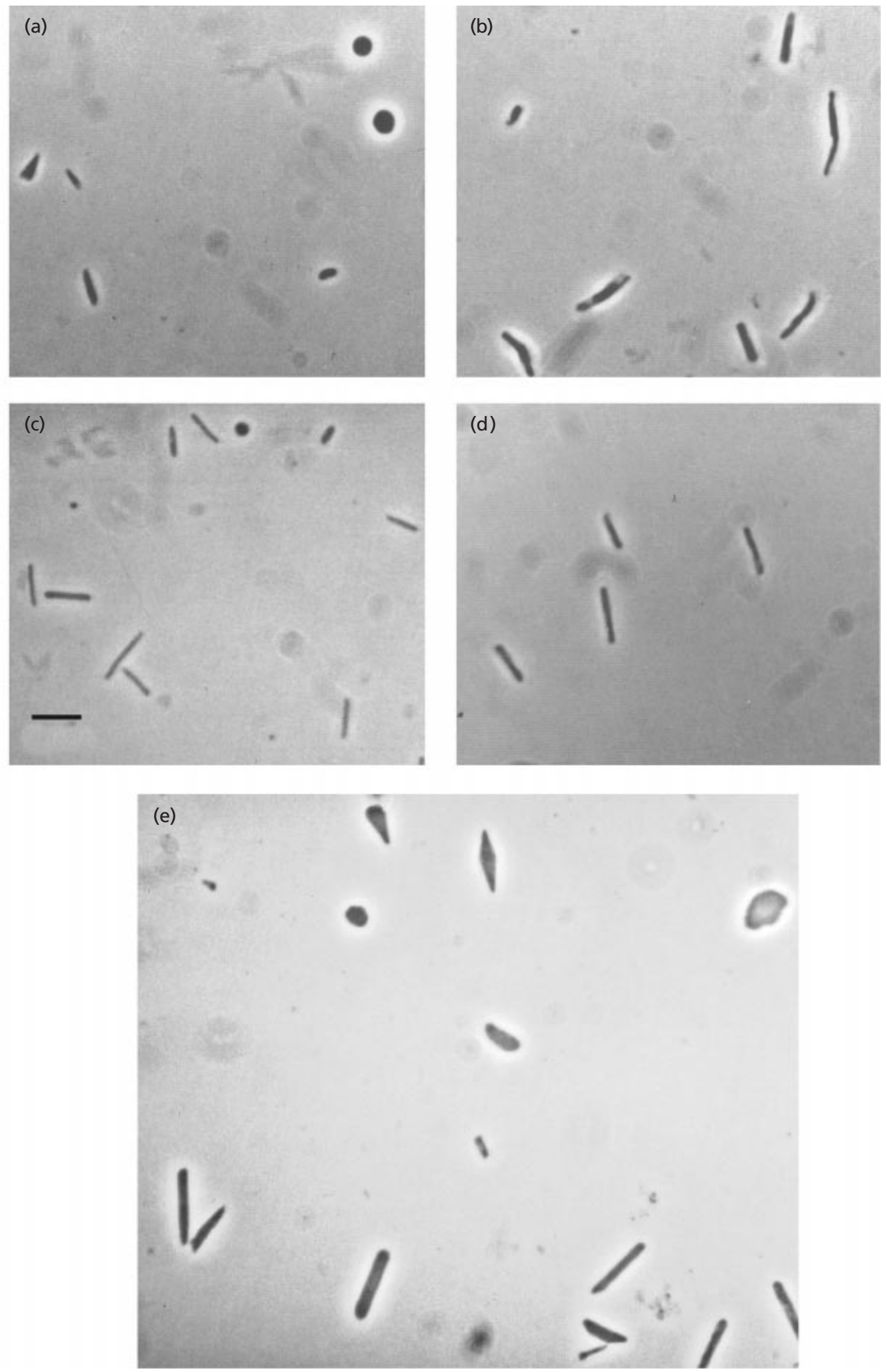

Fig. 1. Phase-contrast micrographs of strain $135^{\top}$ grown in liquid $S-G$ medium containing $25 \%(w / v) ~ N a C l(a-d)$ or $14 \%$ $(\mathrm{w} / \mathrm{v}) \mathrm{NaCl}(\mathrm{e})$ to demonstrate cell shape differentiation. Bar, $5 \mu \mathrm{m}$.

growth. Among the nitrogenous compounds tested, neither bacto-peptone nor nutrient broth (Difco) could serve for growth in liquid culture because of the presence of bile acids, which mediate cell lysis, while gelatin and glycine resulted in weak growth. However, proteose peptone, yeast extract, tryptone and Casamino acids served as good carbon as well as nitrogen sources, mediating good growth. The VPMR 

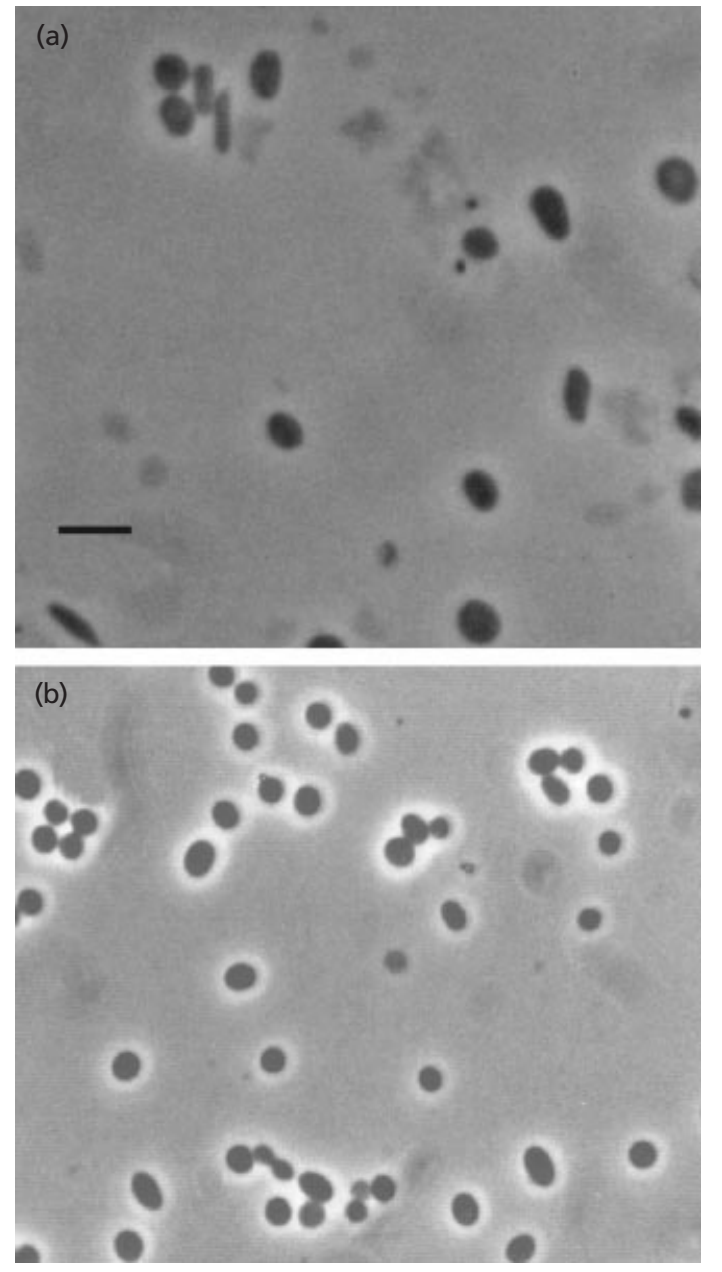

Fig. 2. Cells of strain $135^{\top}$ cultivated on $S-G$ agar at $25 \%(w / v)$ $\mathrm{NaCl}($ a) or $13 \%(w / v) \mathrm{NaCl}$ (b) to demonstrate cell shape differentiation. Bar, $5 \mu \mathrm{m}$.

test was negative. Nitrate reduction, denitrification, indole formation from tryptone, sulfide from cysteine and ammonia from arginine were positive. The strain was sensitive to fusidic acid, bacitracin, nitrofurantoin, novobiocin, anisomycin and rifampicin but was resistant to nystatin, tetracycline, nalidixic acid, trimethoprim, erythromycin, chloramphenicol, streptomycin and penicillin G. Strain $135^{\mathrm{T}}$ was strictly aerobic and no anaerobic growth was observed, even in the presence of nitrate or arginine hydrochloride. Other phenotypic characteristics are listed in the species description below.

As shown for other extremely halophilic archaea (Fernandez-Castillo et al., 1986; Hezayen et al., 2000), strain $135^{\mathrm{T}}$ was able to accumulate PHB up to $40 \%$ $(\mathrm{w} / \mathrm{v})$ of cellular dry weight. In contrast to the other extremely halophilic archaea, strain $135^{\mathrm{T}}$ was able to accumulate PHB up to $15 \%(\mathrm{w} / \mathrm{w})$ of cellular dry weight even when proteose peptone or Casamino acids and yeast extract were used instead of butyric acid.

Cells of strain $135^{\mathrm{T}}$ were rich in carotenoids under all cultivation conditions, showing absorption maxima at wavelengths of $370,390,494$ and $528 \mathrm{~nm}$ with a shoulder at 466-476 $\mathrm{nm}$. These maxima correspond to those of bacterioruberin, which is a characteristic feature of extremely halophilic archaea (Gochnauer et al., 1972; Grant et al., 2001).

\section{Chemotaxonomy: ether lipids, quinones and polar lipids}

The ether lipids comprised only diether lipids, tetraether lipids being absent. The diether lipids present were the diphytanyl derivative $\mathrm{C} 20: \mathrm{C} 20$ and the phytanyl sesterterpanyl derivative $\mathrm{C} 20: \mathrm{C} 25$, in almost equal amounts. Other groups in which $\mathrm{C} 20$ : C25 diethers are present produce either significant amounts of the $\mathrm{C} 20$ : $\mathrm{C} 25$ diether or only traces to small amounts.

Menaquinones were the only respiratory lipoquinones present and comprised MK-8 and MK-8(VIII- $\left.H_{2}\right)$. Furthermore, a sulfated triglycosyl diether and a triglycosyl diether were produced as sole glycolipids; these are absent in the majority of neutrophilic and alkaliphilic members of the family Halobacteriaceae (Table 1).

Table 1. Distinction of genera belonging to the family Halobacteriaceae based on phenotypic properties

Data for reference taxa taken from Hezayen et al. (2001), Kamekura \& Dyall-Smith (1995), McGenity \& Grant (1995), Ihara et al. (1997), Montalvo-Rodríguez et al. (1998) and Tindall et al. (1984). Abbreviations: PGS, phosphatidyl glycerosulfate; $\mathrm{S}_{2}$-DGD, bis-sulfated diglycosyl diether; TGD, triglycosyl diether; S-TGD, sulfated triglycosyl diether. All genera contain phosphatidyl glycerol and methylated phosphatidyl glycerophosphate.

\begin{tabular}{|c|c|c|c|c|c|c|}
\hline Property & Natrialba & Halobacterium & Strain $135^{T}$ & Haloarcula & Natronobacterium & Halogeometricum \\
\hline $\begin{array}{l}\mathrm{Mg}^{2+} \text { required for } \\
\text { growth }(\mathrm{mM})\end{array}$ & 0 & 5 & 0 & 3 & $<10$ & 5 \\
\hline PGS & - & + & - & + & - & - \\
\hline $\mathrm{S}_{2}$-DGD & + & - & - & - & - & - \\
\hline S-TGD & - & + & + & - & - & - \\
\hline TGD & - & + & + & + & - & - \\
\hline $\mathrm{G}+\mathrm{C}$ content $(\mathrm{mol} \%)$ & $60 \cdot 3-63 \cdot 1$ & $66-70 \cdot 9$ & $66 \cdot 9$ & $62 \cdot 7-68$ & $61 \cdot 2-64 \cdot 6$ & $59 \cdot 1$ \\
\hline
\end{tabular}




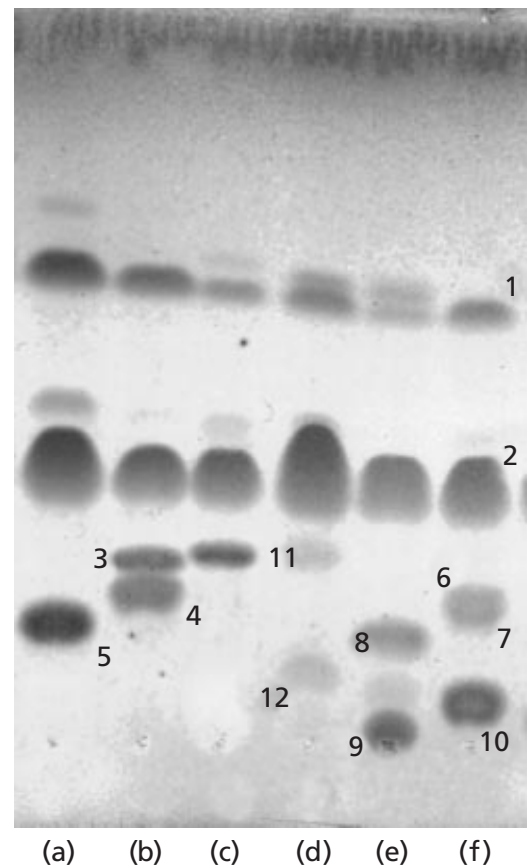

Fig. 3. Thin-layer chromatogram of the total polar lipids of Haloferax mediterranei DSM 1411 (a), Haloarcula vallismortis DSM $3756^{\top}$ (b), Halogeometricum borinquense DSM $11551^{\top}$ (c), strain $135^{\top}$ (d), Natrinema pellirubrum NCIMB $786^{\top}$ (e) and Halobacterium salinarum NRC 34001 (f). Plates were subjected to double development in the solvent chloroform/methanol/acetic acid/water (80:12:15:4, by vol.). Total lipids were visualized using dodecamolybdophosphoric acid and specific spray reagent used to detect functional groups. The lipids were identified as follows (all compounds are the diether derivatives): 1, phosphatidyl glycerol; 2, methylated phosphatidyl glycerophosphate; 3, triglycosyl diether; 4 and 7, phosphatidyl glycerosulfate; 5 and 8 , sulfated diglycosyl diether; 6 , triglycosyl diether; 9, sulfated glycolipid; 10 , sulfated triglycosyl diether; 11 , triglycosyl diether; 12 , sulfated glycolipid.

The polar lipid analysis revealed the presence of phosphatidyl glycerol and methylated phosphatidyl glycerol phosphate, whereas no phosphatidyl glycerosulfate was detected (Fig. 3). Nevertheless, the presence of diether lipids, MK-8 and MK-8(VIII- $\mathrm{H}_{2}$ ) coupled with the presence of polar lipids are characteristic features of the monophyletic group defined by the family Halobacteriaceae (Table 1).

Within the group to which strain $135^{\mathrm{T}}$ belongs, which can be defined both chemically and by 16S rDNA sequence analysis, there are a number of further subgroups that can be distinguished by their physiology (neutrophile or alkaliphile), other phenotypic characteristics and their chemical composition. Within this group, strain $135^{\mathrm{T}}$ is unique at present in producing both a triglycosyl diether lipid and its sulfated derivative. Thus, strain $135^{\mathrm{T}}$ may be distinguished unambiguously from all other known members of this subgroup and from other members of the family Halobacteriaceae.

\section{$\mathbf{G}+\mathbf{C}$ content of the DNA}

The $\mathrm{G}+\mathrm{C}$ content of the DNA of strain $135^{\mathrm{T}}$ was $66.9 \mathrm{~mol} \%$ (mean of three independent determinations), which differs significantly from the value of about $63.5 \mathrm{~mol} \%$ for the most closely related Natronococcus species.

\section{Inference of evolutionary relationships based on the 165 rDNA sequence}

Approximately $99 \%$ (1457 bp) of the 16S rDNA sequence was determined. Initial comparison of the sequence with members of the family Halobacteriaceae revealed that strain $135^{\mathrm{T}}$ grouped consistently with the species Nbt. gregoryi, Nbt. nitratireducens, Ncc. occultus and Ncc. amylolyticus (Fig. 4). Therefore, the novel strain was compared with these three described species and the 16S rDNA sequences of Nab. magadii, Nab. asiatica and Halococcus sp. were used as outgroup sequences to polarize the data. All of the analysis methods consistently grouped strain $135^{\mathrm{T}}$ together with Nbt. nitratireducens. Irrespective of which method of analysis was used, the branching order between the pairs strain $135^{\mathrm{T}} / N b t$. nitratireducens, Ncc. occultus/Ncc. amylolyticus and Nbt. gregoryi could not be resolved unambiguously (Fig. 4). Based on these data alone, it is not possible to conclude whether the pair strain $135^{\mathrm{T}} /$ Nbt. nitratireducens belongs to a monophyletic group together with Natronobacterium.

Although bootstrap values for the pair strain $135^{\mathrm{T}} /$ Nbt. nitratireducens were high, binary similarity values showed a similarity value of $96.4 \%$. This may be attributed to the comparatively long internal edge that connects this group to the rest of the sequences. All distance matrix methods showed that Nbt. gregoryi did not form a unique cluster with strain $135^{\mathrm{T}} / \mathrm{Nbt}$. nitratireducens; however, it should be noted that both the bootstrap values and visual inspection of the rather short internal edges linking the three 'clusters' $\mathrm{Nbt}$. gregoryi, Ncc. occultus/Ncc. amylolyticus and strain $135^{\mathrm{T}} /$ Nbt. nitratireducens showed that no significance should be attached to this branching order. DNAML gave a similar topology to the distance matrix methods, whereas the topology of the DNAPARS dendrogram indicated that Nbt. gregoryi and strain $135^{\mathrm{T}} / \mathrm{Nbt}$. nitratireducens formed a group to the exclusion of members of the genus Natronococcus (Fig. 4). Each of these methods makes different assumptions about the way the dataset is analysed (Felsenstein, 2001), and it is evident that the interpretation of the 'correct' topology is dependent on knowing which of the assumptions hold true in this particular case. Most methods employed also make inherent assumptions that sequence evolution is always divergent and that parallelism and convergent evolution do not play a role (see Sneath, 1989). Indeed, such effects are usually only detectable when one compares independently evolving datasets (see Sneath, 1974). However, it should also be noted that the rather short internal edges are indicative of the fact that additions to the 
(a)

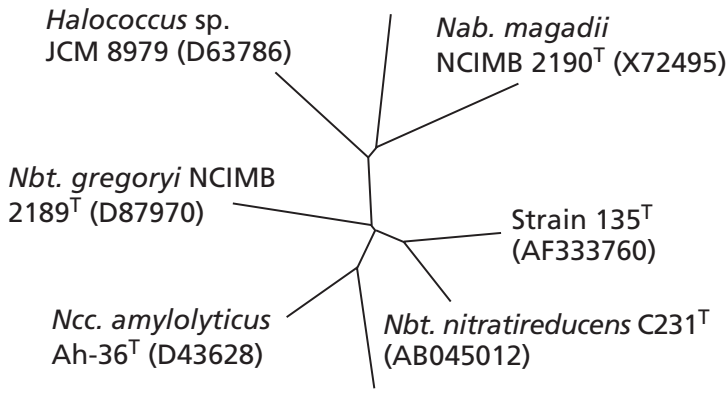

$0.01 \quad$ Ncc. occultus NCIMB $2192^{\top}$ (Z88378)

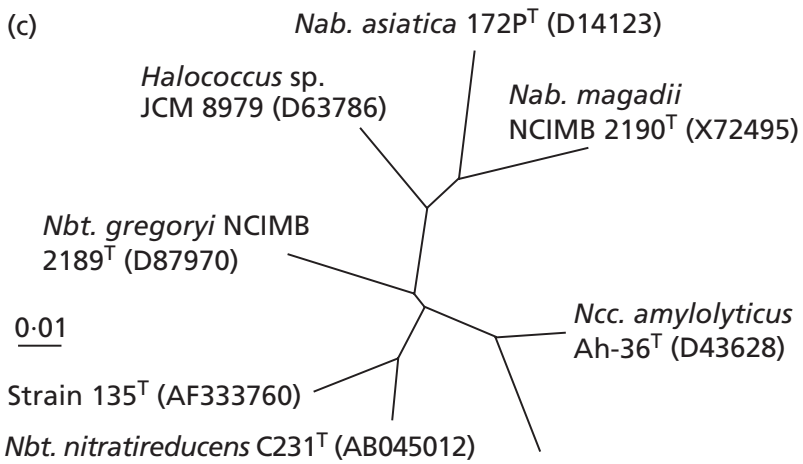

Ncc. occultus NCIMB $2192^{\top}$ (Z88378)
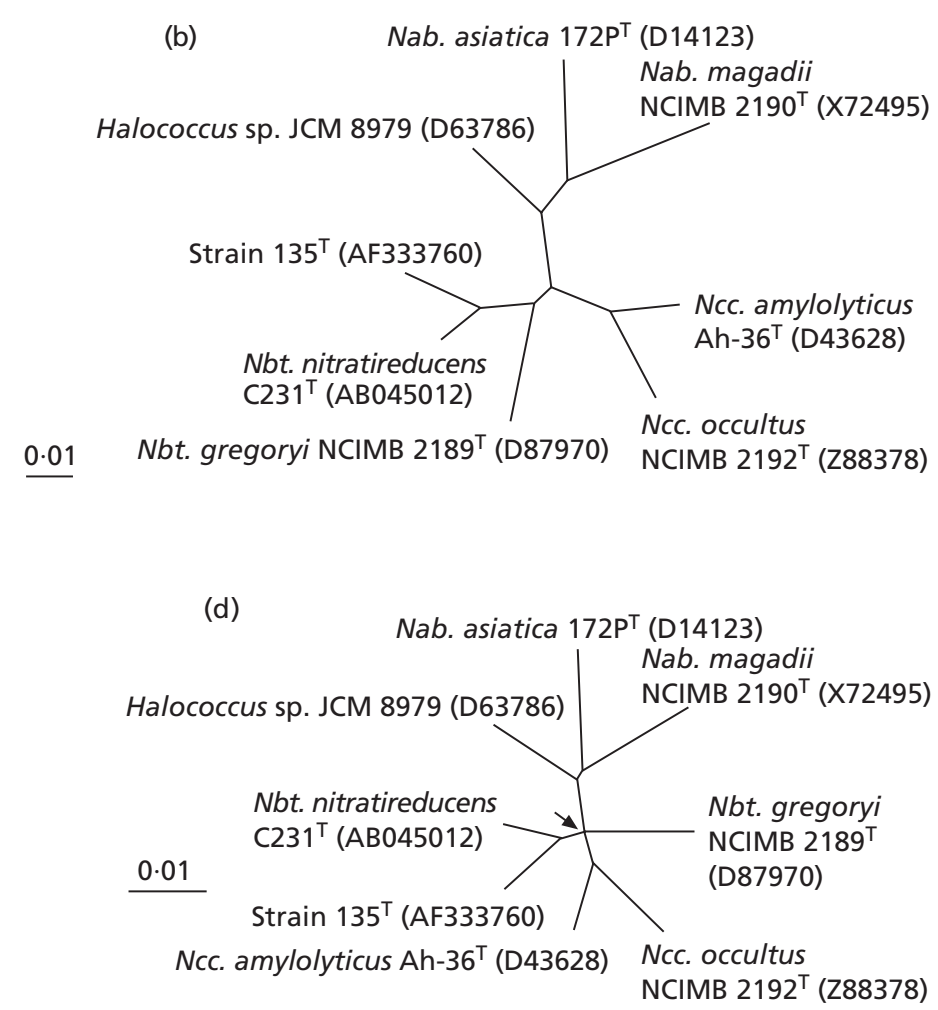

Fig. 4. (a)-(c) $16 \mathrm{~S}$ rDNA sequence-based dendrograms estimated using the programs NEIGHBOR (a), DNAPARS (b) (this version now incorporates branch lengths) and DNAML (c) in PHYLIP version 3.6. (d) 16S rDNA sequence-based dendrogram in which the branches that cannot be unambiguously determined have been collapsed (node indicated by arrow). All trees are unrooted, with the organisms Nab. magadii, Nab. asiatica and Halococcus sp. serving as the outgroup.

dataset may reduce the resolution further, particularly if new sequences are added that join the cluster in the region of the internal edges where the groups $N b t$. gregoryi, strain $135^{\mathrm{T}} /$ Nbt. nitratireducens and members of the genus Natronococcus join. Based on the data presented, it is only possible to conclude that each of the groups Nbt. gregoryi/strain $135^{\mathrm{T}} / \mathrm{Nbt}$. nitratireducens and members of the genus Natronococcus form distinct phyletic groups. While the use of different inference methods indicates that these three groups also comprise a larger phyletic group, it is not possible to determine whether the group Nbt. gregoryi/strain $135^{\mathrm{T}} /$ Nbt. nitratireducens or the group strain $135^{\mathrm{T}} /$ Nbt. nitratireducens/Ncc. occultus/Ncc. amylolyticus is monophyletic to the exclusion of the others. The problem of resolving such branching orders is becoming increasingly apparent in phyletic groups where there are numerous short internal edges. Thus, it is impossible to determine whether each of the three phyletic groups recovered by the methods used should be divided into one, two or three genera. Such problems are to be expected in a potentially continuous dataset and indicate limitations in the use of the $16 \mathrm{~S}$ rDNA sequence data as the sole (and primary) dataset for detecting evolutionary relationships (Fig. 4). Other datasets that also indicate evolutionary relationships need therefore to be taken into consideration, and there are several advantages in using datasets that are not potentially continuous in nature, but which are discontinuous (Tindall, 2000a).

\section{Unravelling the evolutionary and taxonomic status of strain $135^{\top}$}

In the past two decades, increasing attention has been given to the use of $16 \mathrm{~S}$ rDNA sequence data. However, the value of other datasets, such as chemical data, has been underestimated (Tindall, 1992). It is interesting to note that the presence of isoprenoid ether-linked lipids, first described in members of the halobacteria, still serves as a unique chemical marker since Tornabene \& Langworthy (1979) provided evidence of their presence in methanogens, as well as drawing on published data on members of the genera Halobacterium (Faure et al., 1963; Kates et al., 1963), Sulfolobus (Langworthy, 1977b), Caldariella (De Rosa et al., 1974) and Thermoplasma (Langworthy, 1977a). Equally, there is excellent correlation between the presence of dietherlinked isoprenoid ether lipids, the presence of MK-8, MK-8(VIII- $\left.H_{2}\right)$, as well as the presence of phosphatidyl glycerol and methylated phosphatidyl glycerophosphate as the delineation of a unique group 
within the Archaea based on 16S rDNA sequence analysis - the order Halobacteriales. In addition, there is evidence to show that the distribution of dietherlinked isoprenoid lipids in alkaliphilic halobacteria correlates excellently with the 16S rDNA data, in contrast to their physiological properties as alkaliphiles. Thus, members of the genera Natronobacterium, Natronococcus and Natronorubrum produce C20:C20 and C20:C25 diethers in which neither predominates, a feature also found in the neutrophilic members of the group to which members of these genera belong. In contrast, in Natronomonas pharaonis, the C20:C25 diether predominates, while, in alkaliphiles close to members of the genus Halorubrum, the C20:C20 diether predominates (Tindall, 1985). Strain $135^{\mathrm{T}}$, like other members of this phyletic group, also produces $\mathrm{C} 20: \mathrm{C} 20$ and $\mathrm{C} 20: \mathrm{C} 25$ diethers. As pointed out by Tindall (2000b), Nbt. gregoryi is unique within the order Halobacteriales in producing a series of methylated menaquinones, and this features serves to distinguish it from other taxa. Members of the genus Natronococcus are consistently coccoid, never having been shown to produce rod-shaped cells, unlike strain $135^{\mathrm{T}}$, Nbt. gregoryi and Nbt. nitratireducens. Nbt. gregoryi is unique within the present group in that it does not produce a glycoprotein, a feature reported for Natronococcus species and Nbt. nitratireducens. Thus, the data presented indicate that strain $135^{\mathrm{T}}$ and $\mathrm{Nbt}$. nitratireducens should not be placed in the genus Natronobacterium or Natronococcus.

\section{Taxonomy}

Strain $135^{\mathrm{T}}$ shares a high degree of $16 \mathrm{~S}$ rDNA sequence similarity with $N b t$. nitratireducens, and creating a new genus for strain $135^{\mathrm{T}}$ implies that Nbt. nitratireducens also cannot remain within this genus. In view of the close $16 \mathrm{~S}$ rDNA sequence similarity and the need for more detailed studies on the inter-relationship of genotypic and phenotypic properties in determining their relevance to the evolution and taxonomy of this group, we propose that these two strains be placed in a new genus. Thus, we propose the placement of these two organisms in a new genus, Halobiforma gen. nov., for which the designated type species is Halobiforma haloterrestris sp. nov. The abbreviation $H b f$. will be suggested for the new genus.

\section{Description of Halobiforma Hezayen, Tindall, Steinbüchel \& Rehm gen. nov.}

Halobiforma (Ha.lo.bi.for'ma. Gr. n. hals, halos salt; L. prefix bi two; L. n. forma form; N.L. n. Halobiforma the halophile with two different shapes).

Cells are pigmented and are rods, pleomorphic and cocci. Cells are Gram-negative and are motile. May be alkaliphilic or neutrophilic. Major diethers present are C20: C20 and C20:C25. Major polar lipids are phospholipids; glycolipids may be present in some species. When present, the glycolipids are a triglycosyl diether and its sulfated derivative. Phosphatidyl glycerosulfate is not present. The genus constitutes a group that shares more than $96 \% 16 \mathrm{~S}$ rDNA sequence similarity. The type species is Halobiforma haloterrestris.

\section{Description of Halobiforma haloterrestris Hezayen, Tindall, Steinbüchel \& Rehm sp. nov.}

Halobiforma haloterrestris (ha.lo.ter.res'tris. Gr. n. hals, halos salt; L. adj. terrestris belonging to the soil; N.L. adj. haloterrestris from salty soil).

Cells are pigmented and are rods that measure $0.5-1.5 \times 2-8 \mu \mathrm{m}$, pleomorphic and cocci that measure $1.25-2.0 \mu \mathrm{m}$ in diameter. Cells are Gram-negative and are motile. Only rods lyse in distilled water or $1 \%$ $(\mathrm{w} / \mathrm{v})$ bacto-peptone. The optimum temperature for growth is $42{ }^{\circ} \mathrm{C}$. The $\mathrm{pH}$ range for growth is $\mathrm{pH} 6-9 \cdot 2$, with an optimum at $\mathrm{pH} 7 \cdot 5$. The $\mathrm{NaCl}$ range for growth is $2 \cdot 2 \mathrm{M}$ to saturation, with an optimum of 3.4 M NaCl. $\mathrm{NaCl}$ may be replaced to a large extent by $\mathrm{KCl}$. Aerobic, catalase- and oxidase-positive. Acid is produced from xylose, arabinose, glucose, sucrose and maltose, but not from lactose, fructose, galactose or starch or urea. Casein and gelatin are hydrolysed, but not starch. Tweens 20, 40 and 80 are also hydrolysed, but not egg yolk (lecithin). $\mathrm{NH}_{4}$ cannot serve as a nitrogen source, while organic nitrogen compounds such as proteose peptone, Casamino acids and tryptone can serve as nitrogen, carbon and energy sources. The strain accumulates PHB. The $\mathrm{G}+\mathrm{C}$ content of the DNA is $66.9 \mathrm{~mol} \%$. Isolated from a salt soil close to Aswan (Egypt).

The type strain is strain $135^{\mathrm{T}}\left(=\mathrm{DSM} 13078^{\mathrm{T}}=\mathrm{JCM}\right.$ $\left.11627^{\mathrm{T}}\right)$.

\section{Description of Halobiforma nitratireducens (Xin et al. 2001) comb. nov.}

Basonym: Natronobacterium nitratireducens Xin et al. 2001.

The description is identical to that published for $N b t$. nitratireducens by Xin et al. (2001). The type strain is strain C231 $1^{\mathrm{T}}\left(=\right.$ AS $\left.1.1980^{\mathrm{T}}=\mathrm{JCM} 10879^{\mathrm{T}}\right)$.

\section{ACKNOWLEDGEMENTS}

The authors gratefully acknowledge a fellowship provided to F.F.H. by the Egyptian government.

\section{REFERENCES}

De Rosa, M., Gambacorta, A., Milano, L. \& Bu'lock, J. D. (1974). Cyclic diether lipids from very thermophilic acidophilic bacteria. $J$ Chem Soc Chem Commun 453-544.

Dussault, H. P. (1955). An improved technique for staining halophilic bacteria. J Bacteriol 70, 484-485.

Faure, M., Maréchal, J. \& Troestler, J. (1963). Les phosphatides éther des bactéries halophiles. Sur la presence d'un pyrophosphatidylglycerophosphorique chez Halobacterium cutirubrum. C R Hebd Seanc Acad Sci Paris 257, 2187-2190.

Felsenstein, J. (2001). PHYLIP. http://evolution.genetics.washington. edu/phylip.html

Fernandez-Castillo, R., Rodriguez-Valera, F., Gonzales-Ramos, J. 
\& Ruiz-Berraquero, F. (1986). Accumulation of poly( $\beta$-hydroxybutyrate) by halobacteria. Appl Environ Microbiol 51, 214-216.

Gerhardt, P., Murray, R. G. E., Wood, W. A. \& Krieg, N. R. (1994). Methods for General and Molecular Bacteriology. Washington, DC: American Society for Microbiology.

Gibbons, N. E. (1974). Family V. Halobacteriaceae fam. nov. In Bergey's Manual of Determinative Bacteriology, 8th edn, pp. 269-273. Edited by R. E. Buchanan \& N. E. Gibbons. Baltimore: Williams \& Wilkins.

Gochnauer, M. B., Kushwaha, S. C., Kates, M. \& Kushner, D. (1972). Nutritional control of pigment and isoprenoid compound formation in extremely halophilic bacteria. Arch Microbiol 84, 339-349.

Grant, W. D. \& Larsen, H. (1989). Group III. Extremely halophilic archaeobacteria. Order Halobacteriales ord. nov. In Bergey's Manual of Systematic Bacteriology, vol. 3, pp. 2216-2219. Edited by J. T. Staley, M. P. Bryant, N. Pfennig \& J. G. Holt. Baltimore: Williams \& Wilkins.

Grant, W. D., Kamekura, M., McGenity, T. J. \& Ventosa, A. (2001). Class III. Halobacteria class. nov. In Bergey's Manual of Systematic Bacteriology, 2nd edn, vol. 1, pp. 294-301. Edited by D. R. Boone \& R. W. Castenholz. New York, Berlin \& Heidelberg: Springer-Verlag.

Hezayen, F. F., Rehm, B. H. A., Eberhardt, R. \& Steinbüchel, A. (2000). Polymer production by two newly isolated extremely halophilic archaea: application of a novel corrosion-resistant bioreactor. Appl Microbiol Biotechnol 54, 319-325.

Hezayen, F. F., Rehm, B. H. A., Tindall, B. J. \& Steinbüchel, A. (2001). Transfer of Natrialba asiatica B1T to Natrialba taiwanensis sp. nov. and description of Natrialba aegyptiaca sp. nov., a novel extremely halophilic, aerobic, non-pigmented member of the Archaea from Egypt that produces extracellular poly(glutamic acid). Int J Syst Evol Microbiol 51, 1133-1142.

Ihara, K., Watanabe, S. \& Tamura, T. (1997). Haloarcula argentinensis sp. nov. and Haloarcula mukohataei sp. nov., two new extremely halophilic archaea collected in Argentina. Int J Syst Bacteriol 47, 73-77.

Kamekura, M. \& Dyall-Smith, M. L. (1995). Taxonomy of the family Halobacteriaceae and the description of two new genera Halorubrobacterium and Natrialba. J Gen Appl Microbiol 41, 333-350.

Kamekura, M., Osterhelt, D., Wallace, R., Anderson, P. \& Kushner, D. J. (1988). Lysis of halobacteria in bacto-peptone by bile acids. Appl Environ Microbiol 54, 990-995.

Kamekura, M., Dyall-Smith, M. L., Upasani, V., Ventosa, A. \& Kates, M. (1997). Diversity of alkaliphilic halobacteria: proposal for transfer of Natronobacterium vacuolatum, Natronobacterium magadii, and Natronobacterium pharaonis to Halorubrum, Natrialba, and Natronomonas gen. nov., respectively, as Halorubrum vacuolatum comb. nov., Natrialba magadii comb. nov., and Natronomonas pharaonis comb. nov., respectively. Int J Syst Bacteriol 47, 853-857.

Kates, M., Sastry, P. S. \& Yengoyen, L. S. (1963). Isolation and characterization of a diether analogue of phosphatidyl glycerophosphate from Halobacterium cutirubrum. Biochim Biophys Acta 70, 705-707.

Langworthy, T. A. (1977a). Long-chain diglycerol tetraethers from Thermoplasma acidophilum. Biochim Biophys Acta 487, 37-50.

Langworthy, T. A. (1977b). Comparative lipid composition of heterotrophically and autotrophically grown Sulfolobus acidocaldarius. $J$ Bacteriol 130, 1326-1332.

Ludwig, W. \& Strunk, O. (1996). ARB: a software environment for sequence data. Technische Universität München, Munich.

Ludwig, W., Strunk, S., Klugbauer, S., Klugbauer, N., Weizenegger, M., Neumaier, J., Bachleitner, M. \& Schleifer, K. H. (1998). Bacterial phylogeny based on comparative sequence analysis. Electrophoresis 19, 554-568.

Mak, Y. M. \& Ho, K. K. (1992). An improved method for the isolation of chromosomal DNA from various bacteria and cyanobacteria. Nucleic Acids Res 20, 4101-4102.

McGenity, T. J. \& Grant, W. D. (1995). Transfer of Halobacterium saccharovorum, Halobacterium sodomense, Halobacterium trapanicum NRC 34041 and Halobacterium lacusprofundi to the genus Halorubrum gen. nov., as Halorubrum saccharovorum comb. nov., Halorubrum sodomense comb. nov., Halorubrum trapanicum comb. nov., and Halorubrum lacusprofundi comb. nov. Syst Appl Microbiol 18, 237-243.

McGenity, T. J., Gemmell, R. T. \& Grant, W. D. (1998). Proposal of a new halobacterial genus Natrinema gen. nov., with two species Natrinema pellirubrum nom. nov. and Natrinema pallidum nom. nov. Int J Syst Bacteriol 48, 1187-1196.

Mesbah, M., Premachandran, U. \& Whitman, W. B. (1989). Precise measurement of the $\mathrm{G}+\mathrm{C}$ content of deoxyribonucleic acid by highperformance liquid chromatography. Int J Syst Bacteriol 39, 159-167.

Montalvo-Rodríguez, R., Vreeland, R. H., Oren, A., Kessel, M., Betancourt, C. \& López-Garriga, J. (1998). Halogeometricum borinquense gen. nov., sp. nov., a novel halophilic archaeon from Puerto Rico. Int J Syst Bacteriol 48, 1305-1312.

Oren, A., Gurevich, P., Gemmell, R. T. \& Teske, A. (1995). Halobaculum gomorrense gen. nov., sp. nov., a novel extremely halophilic archaeon from the Dead Sea. Int J Syst Bacteriol 45, 747-754.

Oren, A., Ventosa, A. \& Grant, W. D. (1997). Proposed minimal standards for description of new taxa in the order Halobacteriales. Int J Syst Bacteriol 47, 233-238.

Rehm, B. H. A. (2001). Bioinformatic tools for DNA/protein sequence analysis, functional assignment of genes and protein classification. Appl Microbiol Biotechnol 57, 579-592.

Ross, H. N. M. \& Grant, W. D. (1985). Nucleic acid studies on halophilic archaebacteria. J Gen Microbiol 131, 165-173.

Sehgal, S. N. \& Gibbons, N. E. (1960). Effect of metal ions on the growth of Halobacterium cutirubrum. Can J Microbiol 6, 165-169.

Sneath, P. H. A. (1974). Phylogeny of micro-organisms. In Evolution in the Microbial World, pp. 1-39. Symposium of the Society for General Microbiology, no. 24. Edited by M. J. Carlile \& J. J. Skehel. Cambridge: Cambridge University Press.

Sneath, P. H. A. (1989). Analysis and interpretation of sequence data for bacterial systematics: the view from a numerical taxonomist. Syst Appl Microbiol 12, 15-31.

Tamaoka, J. \& Komagata, K. (1984). Determination of DNA base composition by reversed-phase high-performance liquid chromatography. FEMS Microbiol Lett 25, 125-128.

Tindall, B. J. (1985). Qualitative and quantitative distribution of diether lipids in haloalkaliphilic archaebacteria. Syst Appl Microbiol 6, 247-250.

Tindall, B. J. (1990a). A comparative study of the lipid composition of Halobacterium saccharovorum from various sources. Syst Appl Microbiol 13, 128-130.

Tindall, B. J. (1990b). Lipid composition of Halobacterium lacusprofundi. FEMS Microbiol Lett 66, 199-202.

Tindall, B. J. (1992). The family Halobacteriaceae. In The Prokaryotes. A Handbook of Bacteria: Ecophysiology, Isolation, Identification, Applications, 2nd edn, vol. 1, pp. 768-808. Edited by A. Balows, H. G. Trüper, M. Dworkin, W. Harder \& K.-H. Schleifer. New York: Springer.

Tindall, B. J. (2000a). Prokaryotic systematics: a theoretical overview. In Encyclopedia of the Life Sciences (http://www.els.net).

Tindall, B. J. (2000b). Chemical composition of Bacteria and Archaea: a critical evaluation. In Bacterial Diversity and Systematics, pp. 243-258. FEMS Symposium no. 75. Edited by F. G. Priest, A. RamosCormenzana \& B. J. Tindall. New York \& London: Plenum Press.

Tindall, B. J., Ross, H. N. M. \& Grant, W. D. (1984). Natronobacterium gen. nov. and Natronococcus gen. nov., two new genera of haloalkaliphilic archaebacteria. Syst Appl Microbiol 5, 41-57.

Tornabene, T. G. \& Langworthy, T. A. (1979). Diphytanyl and dibiphytanyl glycerol ether lipids of methanogenic archaebacteria. Science 203, 51-53.

Torreblanca, M., Rodríguez-Valera, F., Juez, G., Ventosa, A., Kamekura, M. \& Kates, M. (1986). Classification of non-alkaliphilic halobacteria based on numerical taxonomy and polar lipid composition, and description of Haloarcula gen. nov. and Haloferax gen. nov. Syst Appl Microbiol 8, 89-99. 
Ventosa, A., Gutiérrez, M. C., Kamekura, M. \& Dyall-Smith, M. L. (1999). Proposal to transfer Halococcus turkmenicus, Halobacterium trapanicum JCM 9743 and strain GSL-11 to Haloterrigena turkmenica gen. nov., comb. nov. Int J Syst Bacteriol 49, 131-136.

Wainø, M., Tindall, B. J. \& Ingvorsen, K. (2000). Halorhabdus utahensis gen. nov., sp. nov., an aerobic, extremely halophilic member of the Archaea from Great Salt Lake, Utah. Int J Syst Evol Microbiol 50, 183-190.
Xin, H., Itoh, T., Zhou, P., Suzuki, K. \& Nakase, T. (2001). Natronobacterium nitratireducens sp. nov., a haloalkaliphilic archaeon isolated from a soda lake in China. Int J Syst Evol Microbiol 51, $1825-1829$.

Xu, Y., Zhou, P. \& Tian, X. (1999). Characterization of two novel haloalkaliphilic archaea Natronorubrum bangense gen. nov., sp. nov. and Natronorubrum tibetense gen. nov., sp. nov. Int J Syst Bacteriol 49, 261-266. 